Vol 1. No. 4, Oktober 2021 P-ISSN : 2774-8014, e-ISSN : 2774-7034

\title{
MENANAMKAN PENDIDIKAN KARAKTER MELALUI KEGIATAN PEMBIASAAN DI SD NEGERI 2 TAMBAKAN KECAMATAN GUBUG KABUPATEN GROBOGAN
}

\author{
JASMANA \\ SD Negeri 2 Tambakan Kecamatan Gubug Kabupaten Grobogan \\ Email: jasmana196405@gmail.com
}

\begin{abstract}
ABSTRAK
Kegiatan pembiasaan merupakan proses pembentukan sikap dan perilaku yang relatif menetap dan secara otomatis melalui proses pembelajaran yang berulang-ulang dan dilaksanakan di luar jam pelajaran. Pembiasaan merupakan bagian pendidikan budi pekerti dari pendidikan berkarakter yang dilaksanakan secara berulang sebagai respon terhadap stimulus yang sama. Tujuan penulisan artikel adalah untuk mendeskripsikan program pembiasaan yang dilakukan di SD Negeri 2 Tambakan Kecamatan Gubug Kabupaten Grobogan dengan cara membimbing untuk membentuk karakter siswa. Metode penelitian yang digunakan menggunakan metode penelitian kualitatif deskriptif, sehingga hasil penelitian ini adalah: 1) Program pembiasaan SD Negeri 2 Tambakan Kecamatan Gubug Kabupaten Grobogan terdiri atas 4 kegiatan yaitu kegiatan rutin, kegiatan spontan, kegiatan terprogram dan kegiatan keteladanan. 2) Nilai karakter yang diterapkan dan ditunjukan yaitu religius, peduli lingkungan, tanggung jawab, jujur, dan toleransi. 3). Hambatan dalam penerpan pendidikan karakter di SD Negeri 2 Tambakan Kecamatan Gubug Kabupaten Grobogan adalah faktor lingkungan, faktor peserta didik, faktor keluarga dan faktor guru.
\end{abstract}

Kata Kunci: Pendidikan Berkarakter, Kegiatan Pembiasaan, Sekolah Dasar

\section{ABSTRACT}

Habituation activities are a process of forming attitudes and behaviors that are relatively permanent and automatically through a learning process that is repeated and carried out outside of class hours. Habituation is part of character education from character education which is carried out repeatedly in response to the same stimulus. The purpose of writing the article is to describe the habituation program carried out at SD Negeri 2 Tambakan, Gubug District, Grobogan Regency by guiding to shape the character of students. The research method used is descriptive qualitative research method, so the results of this study are: 1) The habituation program of SD Negeri 2 Tambakan, Gubug District, Grobogan Regency consists of 4 activities, namely routine activities, spontaneous activities, programmed activities and exemplary activities. 2) Character values that are applied and shown are religious, care for the environment, responsibility, honesty, and tolerance. 3). The obstacles in implementing character education in SD Negeri 2 Tambakan, Gubug District, Grobogan Regency are environmental factors, student factors, family factors and teacher factors.

Keywords: Character Education, Habituation Activities, Elementary School

\section{PENDAHULUAN}

Dalam kegiatan sehari-hari, penulis sebagai Kepala Sekolah SD Negeri 2 Tambakan, melihat tujuan dari diselenggarakannya pendidikan di sekolah adalah untuk membantu peserta didik untuk menjadi cerdas dan pintar (smart), dan membantu mereka menjadi manusia yang baik (good). Menjadikan peserta didik cerdas dan pintar, boleh jadi mudah melakukannya, tetapi menjadikan manusia agar menjadi orang yang baik dan bijak, tampaknya jauh lebih sulit atau bahkan sangat sulit. Sedangkan Fungsi dan tujuan dari pendidikan nasional dituangkan dalam UU Nomor 20 Tahun 2003 tentang Sisdiknas pasal 3 yang berbunyi :"Pendidikan nasional berfungsi mengembangkan kemampuan dan membentuk watak serta peradaban bangsa yang bermartabat dalam rangka mencerdaskan kehidupan bangsa, bertujuan untuk berkembangnya potensi peserta didik agar menjadi manusia yang beriman dan bertakwa kepada 
Tuhan Yang Maha Esa, berakhlak mulia, sehat, berilmu, cakap, kreatif, mandiri dan menjadi warga Negara yang demokratis serta bertanggung jawab".

Dengan demikian, sangat wajar apabila dikatakan bahwa problem moral merupakan persoalan akut atau penyakit kronis yang mengiringi kehidupan manusia kapan dan di mana pun. Kenyataan tentang akutnya problem moral inilah yang kemudian menempatkan pentingnya penyelengaraan pendidikan karakter peserta didik di SD Negeri 2 Tambakan.

Menurunnya kualitas moral dalam kehidupan manusia Indonesia dewasa ini, terutama di kalangan peserta didik, menuntut diselenggarakannya pendidikan karakter. Sekolah dituntut untuk memainkan peran dan tanggungjawabnya untuk menanamkan dan mengembangkan nilai-nilai yang baik dan membantu para siswa membentuk dan membangun karakter mereka dengan nilai-nilai yang baik. Pendidikan karakter diarahkan untuk memberikan tekanan pada nilai-nilai tertentu, seperti rasa hormat, tanggungjawab, jujur, peduli, adil dan membantu siswa untuk memahami, memperhatikan, dan melakukan nilai-nilai tersebut dalam kehidupan mereka sendiri.

Pendidikan karakter penting dilakukan untuk kemajuan pendidikan moral di Indonesia ini. Salahudin dan Alkrienciechie (2013:42) memaparkan bahwa karakter merupakan ciri khas seseorang atau sekelompok orang yang mengandung nilai, kemampuan, kapasitas moral, dan ketegaran dalam menghadapi kesulitan dan tantangan. Selanjutnya Kurniawan (2017:29) mengungkapkan karakter seseorang terbentuk dari kebiasaan yang dia lakukan, baik sikap dan perkataan yang sering ia lakukan kepada orang lain.

Sedangkan menurut Wibowo (2013:12) karakter merupakan sifat yang alami dari jiwa manusia yang menjadi ciri khas seseorang dalam bertindak dan berinteraksi dikeluarga dan dimasyarakat. Pengertian karakter juga diungkapkan oleh Samani dan Hariyanto (2013:41) sebagai sesuatu yang khas dari seseorang sebagai cara berfikir dan perilaku untuk hidup dan bekerjasama dalam hubungannya dengan sesama yang dapat membuat keputusan dan mempertanggungjawabkan perbuatannya.

Dari pemaparan dari berbagai pendapat ahli tentang karakter, maka karakter adalah suatu sifat yang khas dimilki oleh seseorang yang mengandung nilai, kemampuan, kapasitas moral dalam berfikir dan bertindak yang terbentuk dari kebiasaan yang dia lakukan saat 10 berinteraksi dengan orang lain di lingkungan sehari-hari keluarga dan masyarakat.

Pendidikan karakter telah menjadi perhatian berbagai negara dalam rangka mempersiapkan generasi yang berkualitas, bukan hanya untuk kepentingan individu warga negara, tetapi juga untuk warga masyarakat secara keseluruhan. Pendidikan karakter memerlukan metode khusus yang tepat agar tujuan pendidikan dapat tercapai. Di antara metode pembelajaran yang sesuai adalah metode pembiasaan.

Anis Ibnatul M, dkk (2013: 1) mengatakan bahwa pembiasaan merupakan kegiatan yang dilakukan secara berulang-ulang agar sesuatu tersebut dapat menjadi kebiasaan. Pembiasaan adalah segala sesuatu yang dilakukan secara berulang untuk membiasakan individu dalam bersikap, berperilaku, dan berpikir dengan benar.

Kegiatan pembiasaan kegiatan karakter peserta didik dapat dilakukan dengan membiasakan perilaku positif tertentu dalam kehidupan sehari-hari. Pembiasaan merupakan proses pembentukan sikap dan perilaku yang relatif menetap dan bersifat otomatis melalui proses pembelajaran yang berulang-ulang, baik dilakukan secara bersama-sama ataupun sendiri-sendiri.

Tujuan penulisan artikel dimaksudkan untuk memberikan gambaran secara umum tentang pelaksanaan kegiatan pembiasaan dalam menanamkan pendidikan karakter di SD Negeri 2 Tambakan Gubug sehingga dapat digunakan sebagai referensi para pembaca terutama para guru dan kepala sekolah ketika melaksanakan pendidikan karakter di sekolahnya masingmasing. 


\section{METODE PENELITIAN}

Jenis penelitian ini adalah penelitian kualitatif. Teknik yang digunakan adalah deskriptif interpretatif. Subyek penelitian adalah kegiatan pembiasaan yang di sasarkan pada siswa yang berstatus sebagai pelajar SD Negeri 2 Tambakan. Setting penelitian ini berada di SD Negeri 2 Tambakan Kecamatan Gubug Kabupaten Gribogan. Data yang dikumpulkan adalah data primer dan data sekunder. Data primer yaitu data berupa aktivitas kegiatan pembiasaan yang dilakukan siswa yang diperoleh dengan pengamatan langsung. Selain itu wawancara dengan siswa, orangtua dan komite sekolah. Data sekunder berupa dokumen kurikulum dari SD Negeri 2 Tambakan. Analisis data menggunakan deskriftif interpretatif.

\section{HASIL DAN PEMBAHASAN}

Pembiasaan merupakan proses pembentukan sikap dan perilaku yang relative menetap dan bersifat otomatis melalui proses pembelajaran yang berulang-ulang dan dilaksanakan di luar jam pembelajaran. Pembiasaan merupakan bagian dari pendidikan budi pekerti dengan ciriciri antara lain: relative menetap, tidak memerlukan fungsi berfifkir yang cukup tinggi, sebagai hasil pengalaman belajar, dan tampil secara berulang-ulang sebagai respons terhadap stimulus yang sama dan ini didukung hasil penelitian dari (Gularso dan Firoini.2015)

Kegiatan Pembiasaan yang dilakukukan oleh SD Negeri 2 Tambakan antara lain Kegiatan rutin, kegiatan spontan, kegiatan terprogram dan kegiatan keteladanan. Pendidikan karakter melalui kegiatan pembiasaan kehidupan keseharian di sekolah dengan keteladanan guru dan disertai penanaman nilai-nilai kemuliaan hidup, yang pasti pendidikan karakter memerlukan keteladanan kepala sekolah dan guru, sandaran nilai-nilai kemuliaan hidup sebagai acuan karakter, konsistensi pelaksanaan, dan tidak memerlukan sarana istimewa. Hal tersebut dikemukakan oleh (Suyanto dalam majalah Policy Brief yang diterbitkan oleh Direktorak Jenderal Pendidikan Dasar edisi 4 Juli 2011). Sebagai upaya untuk meningkatkan keselarasan dan mutu pendidikan karakter. Pendidikan karakter harus masuk dalam setiap aspek kegiatan belajar mengajar, praktek keseharian di sekolah dan terintegrasi dengan setiap kegiatan ekstrakurikuler seperti pramuka. Setelah itu setiap siswa diharapkan mampu menerapkannya di rumah dan lingkungan sekitarnya. Semua aspek pendidikan mulai dari ruang kelas hingga lingkungan tempat tinggal harus tetap berkesinambungan dalam menjaga nilai-nilai pendidikan karakter.

Dari hasil menanamkan pendidikan karakter, nilai karakter yang paling banyak diterapkan SD Negeri 2 tambakan antara lain religius, nilai peduli lingkungan, nilai tanggung jawab, nilai jujur, nilai toleransi dan nilai karakter tersebut diterapkan di dalam kelas maupun di sekolah. Hal ini di dukung hasil penelitian dari (Rusmana. 2019) terdapat lima nilai karakter utama yang bersumber dari Pancasila, yang menjadi prioritas pengembangan gerakan Penguatan Pendidikkan Karakter (PPK), diantaranya religius, nasionalisme, integritas, kemandirian, dan kegotong royongan. Nilai-nilai tersebut tidak dapat berdiri dan berkembang sendiri, melainkan saling berketerkaitan satu sama lain.

Berdasarkan hasil wawancara yang didapat diketahui bahwa strategi yang dilakukan SD Negeri 2 Tambakan adalah dengan kegiatan pembiasaan seperti selalu mengingatkan siswa akan hal baik, memberikan teguran, memberikan contoh atau menjadi teladan, dan menumbuhkan kesadaran siswa. Hal ini selaras dengan (Zubaedi. 2013) yang mengatakan bahwa strategi yang memungkinkan pendidikan karakter bisa berjalan sesuai sasaran setidaktidaknya meliputi tiga hal berikut:

1. Menggunakan prinsip keteladan dari semua pihak, baik orang tua, guru, masyarakat maupun pemimpinnya;

2. Mengunakan prinsip kontinuitas/rutinitas (pembiasaan dalam segala aspek kehidupan)

3. Menggunakan prinsip kesadaran untuk bertindak sesuai dengan nilai-nilai karakter yang diajarkan.

Tujuan yang diharapkan dari menanamkan pendidikan karakter yaitu menginginkan siswa dapat berubah dan memiliki karakter yang baik sehingga dapat menerapkan karakter yang 
dimilikinya bukan hanya di sekolah saja melainkan dalam kehidupanya sehari-hari. Pendidikan karakter bertujuan mengembangkan potensi yang dimiliki peserta didik untuk memberikan keputusan baik-buruk, memelihara apa yang baik, mewujudkan kebaikan itu dalam kehidupan sehari-hari dengan sepenuh hati (Samani dan Haryanto 2013:45-46). Adapun tujuan penulisan artikel dimaksudkan untuk memberikan gambaran secara umum tentang pelaksanaan kegiatan pembiasaan dalam menanamkan pendidikan karakter serta nilai karakter yang diterapkan di SD Negeri 2 Tambakan Gubug Kecamatan Gubug Kabupaten Grobogan.

1. Kegiatan Pembiasaan di SD Negeri 2 Tambakan

Kegiatan pembiasaan di SD Negeri 2 Tambkan adalah sebagai berikut:

a. Kegiatan rutin adalah kegiatan yang dilakukan secara regular dengan tujuan untuk membentuk kebiasaan siswa mengerjakan sesuatu dengan baik.

a) Berjabat tangan. Berjabat tangan dengan siswa tiba di sekolah. Kepala Sekolah dan guru-guru sudah siap di depan pintu pagar menyambut siswa. Siswa putra berjabat tangan dengan bapak guru dan siswa putri berjabat tangan dengan ibu guru. Siswa berjabat tangan tidak hanya dengan guru kelas saja tetapi seluruh guru dan tenaga kependidikan di sekolah. Hal ini didukung hasil penelitian dari (Gularso dan Firoini.2015) kegiatan berjabat tangan akan menambah rasa menghormati siswa terhadap guru, dan menambah keakraban siswa dan guru.

b) Berdoa sebelum memulai kegiatan Kegiatan ini bertujuan untuk membiasakan peserta didik berdoa sebelum memulia segala aktifitas. Kegiatan dilaksanakan setiap pagi secara terpusat dari ruang informasi dimana pada setiap pagi dengan petugas yang terjadwal

c) Membaca Asmaul Husna, Kegiatan ini bertujuan membiasakan peserta didik untuk berdzikir, mengingat nama - nama Allah. Kegiatan ini dilaksanakan secara terpusat dari ruang insformasi dengan petugas yang terjadwal.

d) Upacara, pelaksanaan upacara bendera hari senin dengan petugas upacara bergantian mulai dari klas IV, V dan VI. Mengikuti upacara dengan hikmad akan bermanfaat besar bagi siswa terutama sekali dalam membentuk karakter positif. Karakter positif yang dibentuk pada diri siswa antara lain: disiplin, cinta tanah air, tenggang rasa, sikap sosial dan masih banyak yang lainnya.

e) Sholat berjamaah , untuk ketertiban sholat berjamaah guru dibantu oleh petugas dari siswa itu sendiri. Guru dan siswa melaksanakan sholat dhuha pada waktu istirahat pertama dan melaksanakan sholat dhuhur berjamaah.

f) Infaq Jum'at, siswa dibiasakan berinfaq seikhlasnya untuk kelas maupun sekolah. Infaq ini digunakan untuk keperluan kelas masing-masing.

g) Pramuka, adalah proses pendidikan di luar lingkungan sekolah dan di luar lingkungan keluarga dalam bentuk kegiatan menarik, menyenangkan, sehat, teratur, terarah, praktis yang dilakukan di alam terbuka dengan prinsip dasar kepramukaan dan metode kepramukaan, yang sasaran akhirnya pembentukan watak, akhlak, dan budi pekerti luhur. Kepramukaan adalah sistem pendidikan kepanduan yang disesuaikan dengan keadaan, kepentingan, dan perkembangan masyarakat, dan bangsa Indonesia.

b. Kegiatan spontan. Kegiatan spontan adalah kegiatan yang tidak ditentukan tempat dan waktunya. Kegiatan ini bertujuan untuk menanamkan kebiasaan pada saat itu juga.

a) Mengucapkan salam, siswa dibiasakan mengucapkan slam kepada kepala sekolah, guru, penjaga maupun kepada sesame siswa saat bertemu.

b) Membiasakan mengucapkan kata-kata sopan dan santun, tolong, maaf permisi dan terima kasih. Siswa dibiasakan mengucapkan kata tolong saat meminta pertolongan, siswa dibiasakan mengucapkan permisi jika hendak melakukan sesuatu, siswa dibiasakan mengucapkan maaf jika melakukan kesalahan dan siswa dibiasakan mengucapkan terima kasih saat mendapat bantuan dan menerima sesuatu dari orang lain. 
c) Membuang sampah pada tempatnya. Siswa dibiasakan membuang sampah di tempat yang telah disediakan. Sekolah sudah menyediakan tempat sampah yang yang dipilah antara sampah basah dan kering/plasik dan sampah logam di beberapa sudut strategis.

d) Membiasakan budaya antri. Siswa dibiasakan untuk antri saat jajan, berwudlu, saat mencuci tangan dan berjabat tangan dengan guru.

e) Membiasakan meminta ijin. Siswa dibiasakan meminta ijin saat pelajaran berlangsung, saat keluar kelas. Siswa juga dibiasakan meminta ijin jika meminjam atau memakai barang-barang yang bukan miliknya.

c. Kegiatan terprogram yaitu kegiatan yang direncanakan dengan maksud untuk mendukung kegiatan pembiasaan terhadap siswa. Kegiatan ini meliputi hal-hal berikut ini:

a) Kegiatan memperingati hari besar, egiatan ini seperti pada perayaan Idhul Adha, siswa telah digiatkan untuk latihan berkurban, siswa kelas atas dilibatkan dalam pemotongan dan pembagian daging hewan kurban. Kegiatan menyantuni ayak yatim pada tanggal 10 muharam, kegiatan peringatan hari kemerdekaan Republik Indonesia (17 Agustus), peringatan hari pendidikan nasional dll.

b) Pesantren Ramadhan. Pesantren Ramadhan dilakukan selama satu hari satu malam di sekolah. Siswa putra dan siswa putri melaksanakan pesantren Ramadhan di hari yang berbeda dengan kegiatan yang sama. Pada Pesantren Ramadhan siswa dibiasakan untuk mengingat Allah setiap saat dengan memperbanyak dzikir, membaca Al-Qur'an, sholat sunah dan menjaga lisan.

c) Karyawisata, kegiatan ini dilaksanakan setahun sekali dengan peserta kelas atas. Tujuan agar siswa bisa mempelajari sejarah bangsa Indonesia, mempelajari saint dan teknologi serta menjalin keakraban dan melatih kerja sama antar siswa maupun guru.

d. Kegiatan teladan adalah kegiatan dengan pemberian contoh dari guru dan tenaga pendidik yang lain kepada siswa. Kegiatan teladan meliputi hal-hal berikut.
a) Berpakaian rapi
b) Datang lebih awal
c) Berkata jujur
d) Menyambut tamu dengan ramah
e) Hidup sederhana
f) Suka menolong

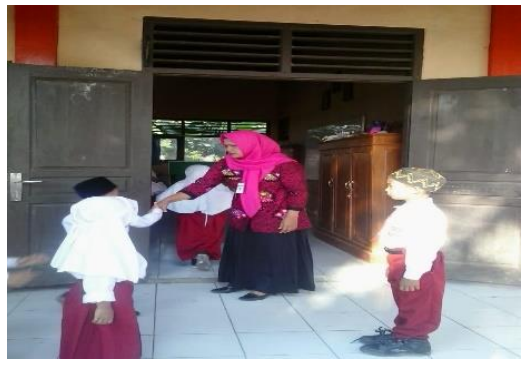

Gambar 1. Bersalaman dengan guru sebelum masuk kelas

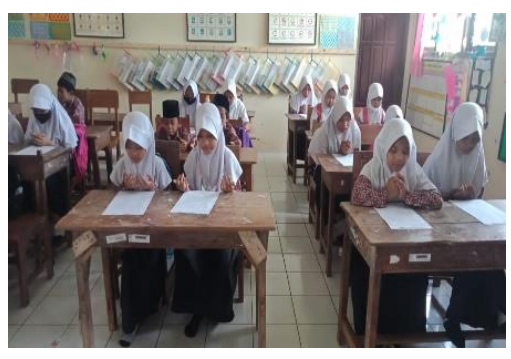

Gambar 2. Berdoa dan membaca asmaul husna sebelum pelajaran

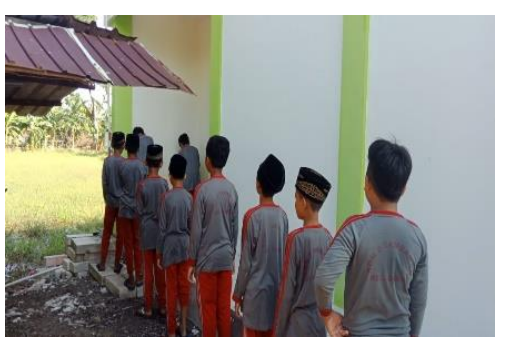

Gambar 3.

Membudidayakan budaya antri dan bersabar 


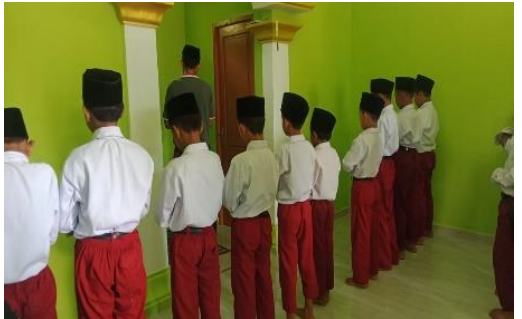

Gambar 4. Sholat dhuhur berjamaah

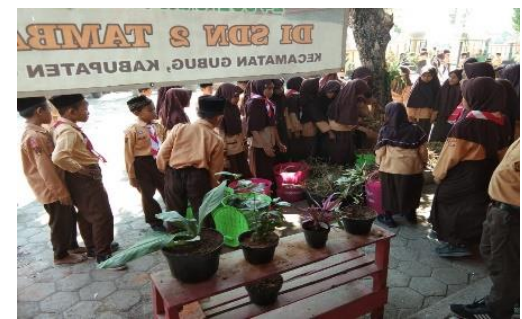

Gambar 5. Kegiatan pramuka pada hari Jumat sore

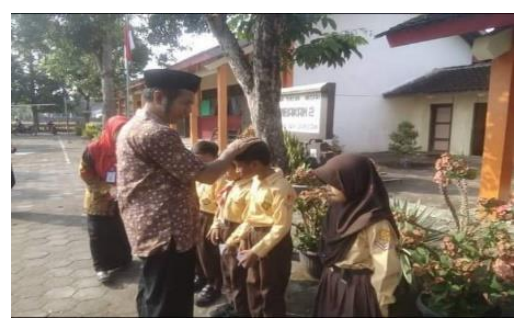

Gambar 6. Kegiatan menyantuni anak yatim pada 10 muharram

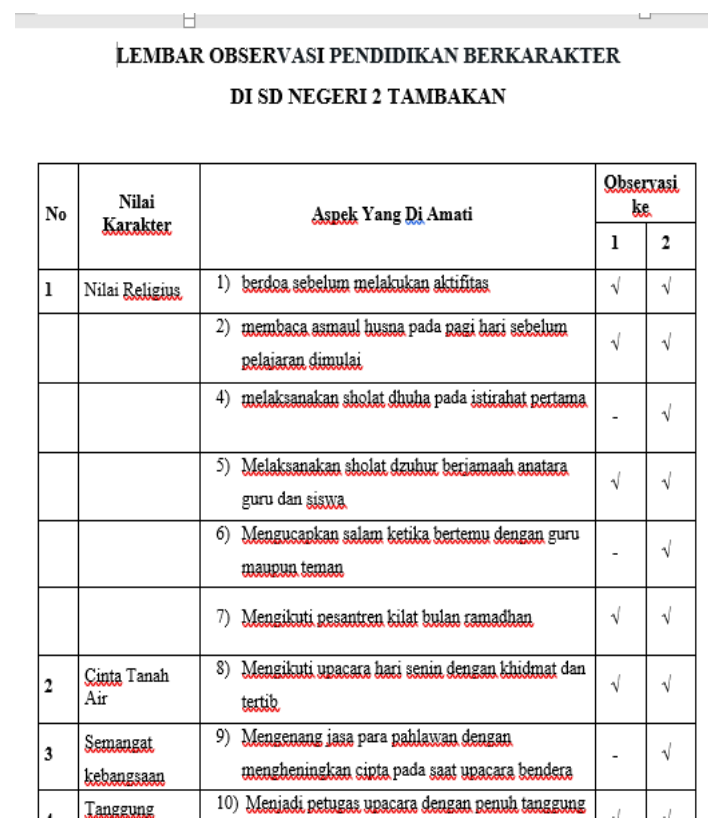

\begin{tabular}{|c|c|c|c|c|}
\hline \multirow[t]{2}{*}{ No } & \multirow{2}{*}{$\begin{array}{c}\text { Nilai } \\
\text { Karakter }\end{array}$} & \multirow[t]{2}{*}{ Aspek Yang Di Amati } & \multicolumn{2}{|c|}{$\begin{array}{l}\text { Obserxasi } \\
\text { ke. }\end{array}$} \\
\hline & & & 1 & 2 \\
\hline & & $\begin{array}{l}\text { 14) Tidak bertengkar dengan teman atau tidak suka } \\
\text { mengeiek teman }\end{array}$ & $\sqrt{ }$ & $\sqrt{ }$ \\
\hline \multirow[t]{3}{*}{6} & Disiplin & 15) Datang be sekclah tepat waltu & - & $\sqrt{ }$ \\
\hline & & $\begin{array}{l}\text { 16) Mengerjakan tygag yang diberikan oleh baspak ibu } \\
\text { guru sesuai jadwal }\end{array}$ & $\sqrt{ }$ & $\sqrt{ }$ \\
\hline & & 17) Melaksanakan tugas piket kebersihana & - & $\sqrt{ }$ \\
\hline \multirow[t]{3}{*}{7} & $\begin{array}{l}\text { Nilai Reduli } \\
\text { Sosial }\end{array}$ & 18) Memberikan infak seikchlasnva tian hari iumat & $\sqrt{ }$ & v \\
\hline & & 19) Menjenguk teman ketika sakit & $\sqrt{ }$ & $\sqrt{ }$ \\
\hline & & $\begin{array}{l}\text { 20) Membantu teman yang mengalami kesulitan } \\
\text { dalam pelajiran }\end{array}$ & $\sqrt{ }$ & $\sqrt{ }$ \\
\hline \multirow[t]{2}{*}{8} & $\begin{array}{l}\text { Reduli } \\
\text { Lingkungan }\end{array}$ & 21) Membuat sampah pada tempatwya & $\sqrt{ }$ & $\checkmark$ \\
\hline & & $\begin{array}{l}\text { 22) Melakssanakan kerja bhakt membersihtkan } \\
\text { lingkungan }\end{array}$ & $\sqrt{ }$ & $\sqrt{ }$ \\
\hline & Komunikatif & 23) Bestanxa saat pembelajaran yang belum & & \\
\hline
\end{tabular}

\section{Data observasi pelaksanaan kegiatan pembiasaan pendidikan berkarakter terhadap siswa SD Negeri 2 Tambakan}

2. Nilai Karakter yang Diterapkan

Nilai karakter yang dihasilkan dari kegitan Pembiasaan yang dilaksanakan di SD Negeri

2 Tambakan melaui kegiatan rutin, kegiatan spontan, kegiatan terprogram dan kegiatan keteladanan adalah sebagai berikut;

a. Nilai Religius, dengan membiasakan berdoa sebelum melakukan aktifitas, membaca asmaul husna dan melaksanakan sholat dhuha maupun sholat dzuhur berjamaah.

b. Nilai Cinta tanah air, dengan upacara bendera akan meningkatkan rasa nasionalisme.

c. Nilai semangat kebangsaan, Melaui upacara bendera kita bisa mengenang jasa para pahlawan dan mensyukuri kemerdekaan Indonesia

d. Nilai Tanggung jawab, Tertib dan Disiplin, melatih rasa tanggung jawab peserta didik yang menjadi petugas upacara, melalui kegiatan pramuka kita melatih peserta didik untuk bersikap tertib dan disiplin dan melaitih jiwa kepemimpinan peserta didik

e. Nilai Peduli Sosial, dengan beramal pada hari jumat,kita melatih anak untuk peduli pada lingkungan sekitar, dan menyisihkan sebagian uang saku untuk kepentingan social.

f. Nilai Peduli Lingkungan, peduli terhadap kebersihan lingkungan sekolah dengan membuang sampah pada tempatnya, melaksanakan piket kelas untuk menjaga kebersihan lingkungan kelas, dan melatih tanggung jawabnya

g. Nilai tertib, dengan membiasakan budaya antre baik saat bersalaman dengan guru, mencuci tangan dll. 
h. Nilai Bersahabat/Komunikatif, berkata dengan sopan, baik bicara dengan guru atau sesame teman, menjaga kesopanan dan meminta izin saat masuk atau keluar ruangan

i. Nilai Toleransi, dengan menghargai teman yang berbeda agama saat memperingati hari besar agamanya.

j. Nilai Gemar Membaca dan Berfikir Kritis, dengan adanya lomba cerdas cermat akan meningkatkan peserta didik untuk gemar membaca dan berfikir kritis untuk menghadapai lomba baik tingkat kecamatan maupun kabupaten.

k. Nilai Menghargai Prestasi, siswa akan menghargai hasil keras temannya dan ikut merasa bangga atas prestasi yang diraih temannya dan termotivasi untuk lebih giat belajar.

1. Rasa Ingin Tahu, dengan karya wisata seperti ke museum akan meningkatkan rasa ingin tahu siswa terhadap sejarah, sains dan teknologi.

m. Nilai Tertib dan Disiplin, dengan berpakai rapi saat berada di sekolah dan datang ke sekolah tepat waktu

n. Nilai Kerja Keras, dengan rajin belajar dan mengerjakan tugas-tugas yang diberikan oleh guru

o. Nilai Jujur, berkata jujur dan apa adanya, berani mengakui kesalahannya dan meminta maaf dan mengerjakan tugas sendiri dan tidak mencontek saat ulangan

3. Masalah yang Dihadapi dan Cara Mengatasi

Berdasarkan hasil observasi terdapat hambatan dalam kegiatan pembiasaan pendidikan

karakter di SD Negeri 2 Tambakan. Selama pelaksanaan Kegiatan-kegiatan pembiasan Pendidikan karakter terdapat beberapa masalah yang dihadapi di SD Negeri 2 Tambakan antara lain:

1. Faktor Lingkungan, lingkungan buruk sering kali membawa dampak buruk juga bagi karakter siswa, misalnya di lingkungan keluarga peserta didik yang sering berkata kotor dan tidak menjaga sopan santun akan ditiru oleh peserta didik dimanapun dia berada termasuk di dalam lingkungan sekolah.

2. Faktor orang tua yang bersikap masa bodo dan terlalu sibuk dengan urusannya sendiri, orang tua yang tidak perhatian terhadap perkembangan pendidikan anaknya, akan mempengaruhi sikap dan perilaku pesrta didik, mereka akan sulit untuk diatur dan dinasehati.

3. Faktor peserta didik, ada sebagian peserta didik yang memiliki motivasi rendah dalam proses pembelajaran, pasif dalam mengikuti pembelajaran di kelas dan sebagian siswa acuh tak acuh, cuek masa bodo dan susah diberitahu terhadap peraturan dan tata tertib sekolah.

4. Faktor guru, kurangnya waktu yang dimiliki untuk bersama siswa sehingga tidak bisa sepenuhnya mengawasi siswa

Cara mengatasi masalah selama melaksanakan kegiatan pembiasan pendidikan karakter yang dilakukan oleh SD Negeri 2 Tambakan adalah:

1. Faktor Lingkungan, cara meminimalisasi dari dampak lingkungan buruk untuk peserta didik adalah dengan memberikan siswa masukan dan tidak bosan mengingatkan siswa untuk bersikap baik.

2. Faktor orang tua yang bersikap masa bodo dan terlalu sisbuk dengan urusannya sendiri, cara meminimalisasinya dengan dilakukan pertemuan orang tua unutk membicarakan bagaimana cara yang baik dalam menerapkan pendidikan karakter siswa.

3. Faktor peserta didik cara mengatasi peserta didik yang memiliki motivasi yang rendah dalam pembelajaran yaitu dengan berbicara dengan peserta didik tentang yang dihadapi dalam belajar kemudian mencari solusi yang baik bagi peserta didik jika diperlukan bisa dibicara kan dengan orang tua peserta didik. Sedangkan peserta didik yang cuek masa bodo dan susah diberitahu, cara meminimalisasinya dengan memberikan peringatan, teguran dan bersikap tegas kepada peserta didik. 
4. Faktor guru, kurangnya waktu yang dimiliki untuk bersama peserta didik sehingga tidak bisa sepenuhnya mengawasi peserta didik, cara meminimalisasinya dengan melakukan koordinasi dengan semua guru, kepala sekolah, penjaga sekolah maupun dengan orang tua.

Berikut penelitian terkait dengan pelaksanaan penanaman pendidikan berkarakter. Penelitian yang dilakukan (Rusmana, 2019) yang berjudul "Penanaman Pendidikan Berkarakter di SD". Penelitian ini mengungkapkan bahwa hambatan dalam penanaman pendidikan berkarakter antara lain: Pertama, kurangnya waktu guru bersama siswa sehingga guru tidak bisa mengawasi siswa secara full. Kedua, siswa yang susah mendengarkan nasehat guru. Ketiga, orang tua siswa yang berupa kurangnya waktu dan perhatian mereka terhadap anaknya. Relevansi penelitian ini dengan penelitian yang dikembangkan oleh penulis memiliki kesamaan yaitu terletak pada faktor lingkungan, peserta didik, baik di lingkungan sekolah maupun lingkungan tempat tinggal, sehingga perlu pemecahan masalah yang bersifat menyeluruh sehingga setiap permasalahan atau hambatan pada setiap peserta didik bisa teratasi dengan baik. Sehingga anak-anak akan tumbuh menjadi pribadi yang berkarakter apabila dapat tumbuh pada lingkungan berkarakter, sehingga hakikat setiap anak yang dilahirkan dapat berkembang secara optimal.

\section{KESIMPULAN}

Berdasarkan hasil kegiatan pembiasaan pendidikan karakter di SD Negeri 2 Tambakan disimpulkan bahwa kegiatan pembiasaan merupakan proses pembentukan sikap dan perilaku yang relatif menetap dan bersifat otomatis melalui proses pembelajaran yang berulang-ulang dan dilaksanakan di luar jam pelajaran. Pembiasaan merupakan bagian dari pendidikan budi pekerti sebagai respons terhadap stimulus yang sama. kegiatan pembiasaan di SD Negeri 2 Tambakan terdiri atas 4 kegiatan yaitu kegiatan rutin, kegiatan spontan, kegiatan terprogram dan kegiatan keteladanan

Dengan kegiatan pembiasaan berkarakter akan membentuk karakter siswa seperti religius, kejujuran, tanggung jawab, dan disiplin. Meningkatkan kondisi mental dan moral individu siswa, pendidikan berkarakter berperan penting dalam mempengaruhi kemampuan berfikir individu siswa dalam mengambil keputusan dan rasa tanggung jawab yang besar.

Pendidikan berkarakter juga meningkatkan karakter guru dalam mengembangkan nilainilai etika dan estetika inti seperti kepedulian, kejujuran, keadilan, tanggung jawab, dan rasa hormat terhadap diri dan orang lain. Mendukung kinerja guru seperti ketekunan, etos kerja yang tinggi, dan kegigihan-sebagai basis karakter yang baik. Serta komitmen guru dalam mengembangkan karakter peserta didik dalam bentuk perilaku yang dapat diamati dalam kehidupan sekolah sehari-hari. Sehingga dengan pendidikan berkarakter mampu mempersiapkan peserta didik menjadi warga negara yang memiliki kemampuan, kemauan,dan menerapkan nilai-nilai pancasila dalam kehidupan sebagai warga negara.

\section{DAFTAR PUSTAKA}

Agus, Wibowo. (2013). Pendidikan Karakter di Perguruan Tinggi. Yogyakarta: Pustaka Pelajar

Anas, Salahudin, \& Irwanto, Alkrienciehie. 2013. Pendidikan Karakter. Bandung: CV Pustaka Setia

Anis Ibnatul, M dkk. (2013). Pendidikan Nasionalisme melalui Pembiasaan di SD Negeri Kuningan 02 Semarang Utara. Jurnal: UNES

Gularso, Dhiniaty, dan Firoini, Khusnul Anso. (2015). Pendidikan Karakter melalui Program Pembiasaan di SD Islam Terpadu Insan Utama Bantul Yogyakarta. Trihayu: Jurnal Pendidikan Ke-SD-an

Kurniawan, Syamsul. (2017). Pendidikan Karakter: Konsepsi dan Implementasinya secara Terpadu di Lingkungan Keluarga, Sekolah, Perguruan Tinggi, dan Masyarakat. Yogyakarta: Ar-Ruzz Media 
Muchlas, Samani \& Hariyanto. (2013). Konsep dan Model: Pendidikan Karakter. Bandung: PT Remaja Rosdakarya

Rusmana, Adistia Oktafiani. (2019). Penerapan pendidikan karakter di SD. Jurnal Eduscience Volume 4 Nomor 2

Zubaedi. (2013). Desain Pendidikan Karakter. Jakarta: Kencana 